\title{
The reasons of strobilurin resistance of Cercospora beticola (cercospora leaf spot) isolates in Wielkopolska region
}

\section{Przyczyny odporności izolatów Cercospora beticola (chwościk buraka) na strobiluryny w Wielkopolsce}

\author{
Katarzyna Pieczul*, Agnieszka Perek
}

\begin{abstract}
Summary
Leaf spot caused by Cercospora beticola is one of the most serious diseases of sugar beet. Various fungicide groups are used to control this disease and among them also strobilurin based products. The aim of the study was to analyze the causes of strobilurin resistance of $C$. beticola isolates collected in Wielkopolska region. The strobilurin inhibits mitochondrial respiratory processes and mutations occurring in the cytochrome b gene (cytb) are the most important reason of $C$. beticola strobilurin resistance. An increasing activity of an alternative oxidase (AOX) also plays an important role in resistance occurring in $C$. beticola isolates. The sequence of cytochrome $b$ gene of $C$. beticola isolates were analyzed. Mutations $\mathrm{G} 143$ and $\mathrm{F} 129 \mathrm{~L}$ - the main determinants of strobilurin resistance were no found. However, an increased strobilurin resistance level of the isolates is caused by higher activity of alternative oxidase, which replaces the function of cytochrome $b$ in the respiratory pathway.
\end{abstract}

Key words: cercospora leaf spot; Cercospora beticola; strobilurin resistance

\section{Streszczenie}

Chwościk wywoływany przez Cercospora beticola należy do najpoważniejszych chorób buraka cukrowego. Do ochrony upraw buraka wykorzystywane są fungicydy z różnych grup chemicznych, także strobiluryny, które hamują procesy oddechowe zachodzące w mitochondriach. Mutacje pojawiające się w genie cytochromu b (cytb) są najważniejszą przyczyną nabywania odporności na strobiluryny przez izolaty $C$. beticola. Wśród pozostałych przyczyn odporności wymienia się wzrost aktywności alternatywnej oksydazy. Celem badań była analiza przyczyn podwyższonej odporności na piraklostrobinę izolatów $C$. beticola zbieranych na terenie Wielkopolski. W badanym fragmencie genu cytochromu b izolatów C. beticola nie stwierdzono mutacji G143A oraz F129L, które wymieniane są wśród podstawowych czynników warunkujących odporność na strobiluryny. Zwiększona odporność badanych izolatów spowodowana jest wzmożoną aktywnością alternatywnej oksydazy, zastępującej funkcję cytochromu b w szlaku oddechowym.

Słowa kluczowe: chwościk buraka; Cercospora beticola; odporność na strobiluryny

Instytut Ochrony Roślin - Państwowy Instytut Badawczy

Zakład Mikologii

Władysława Węgorka 20, 60-318 Poznań

*corresponding author: k.pieczul@iorpib.poznan.pl 


\section{Wstęp / Introduction}

Chwościk buraka jest jedną z najważniejszych chorób buraka cukrowego w Polsce. Chorobę wywołuje grzyb Cercospora beticola Sacc. W sprzyjających patogenowi warunkach rozwojowych uprawy buraka cukrowego wymagają stosowania intensywnej ochrony chemicznej (Piszczek 2010). Przez wiele lat podstawowymi fungicydami stosowanymi w ochronie buraka były substancje z grup benzimidazoli i triazoli, co wpłynęło na rozwój odporności izolatów $C$. beticola na obydwie grupy fungicydów (Campbell i wsp. 1998; Briere i wsp. 2001; Weiland i Halloin 2001; Karaoglanidis i Thanassoulopoulos 2003). W ostatnich latach do ochrony buraka cukrowego przed chwościkiem zalecane są substancje z grup strobiluryn, na które izolaty $C$. beticola także nabywają odporność.

Strobiluryny (fungicydy grupy C3 - QoI) hamują procesy oddechowe zachodzące $\mathrm{w}$ mitochondriach przez połączenie się $\mathrm{z}$ kompleksem cytochromowym $\mathrm{bc}_{1}$, należącym do III kompleksu oddechowego. Powoduje to zablokowanie transferu elektronów pomiędzy cytochromem b i c $c_{1}$ przez co następuje zahamowanie syntezy ATP (adenozynotrójfosforan) prowadzące do deficytów energetycznych u grzybów wrażliwych na strobiluryny (Fernandez-Ortuno i wsp. 2008; Fisher i Meunier 2008). Mutacje punktowe pojawiające się w genie cytochromu b (cytb) są najważniejszą przyczyną nabywania przez izolaty C. beticola odporności na strobiluryny. Powodują one zmianę w sekwencji aminokwasów białka cytochromu b uniemożliwiającą przyłączanie fungicydu. Dotychczas opisanych zostało kilka mutacji odpowiedzialnych za odporność izolatów, $\mathrm{z}$ czego mutacje polegające na zamianie w 143 pozycji kodonu glicyny alaniną (G143A) oraz 129 zamiana fenyloalaniny leucyną mają znaczenie dominujące. Mutacje te zostały opisane u różnych gatunków grzybów patogenicznych dla roślin, także u $C$. beticola (Gisi i wsp. 2002; Fernandez-Ortuno i wsp. 2008; Malandrakis i wsp. 2011; Bolton i wsp. 2013). Wśród pozostałych przyczyn odporności izolatów wymienia się m.in. wzrost aktywności alternatywnej oksydazy zastępującej funkcję blokowanego cytochromu b oraz działanie białek błonowych - ABC (ATP-binding cassette) i MFS (major facilitator superfamily) usuwających $\mathrm{z}$ wnętrza komórek grzyba szkodliwe substancje (Fernandez-Ortuno i wsp. 2008). Ze względu na stosowanie strobiluryn do ochrony buraków w Polsce, nabywanie odporności przez izolaty $C$. beticola stanowi niekorzystne zjawisko.

Celem badań była analiza przyczyn podwyższonej odporności na strobiluryny izolatów $C$. beticola pochodzących z terenu Wielkopolski.

\section{Materiały i metody / Materials and methods}

\section{Izolaty}

W pracy wykorzystano izolaty $C$. beticola zbierane w latach 2012 i 2013 na terenie Wielkopolski. Wszystkie próby pochodziły $\mathrm{z}$ naturalnie porażonych fragmentów liści buraka cukrowego. Izolacji kultur grzybów dokonywano ze świeżego materiału roślinnego. Fragmenty liści z objawami chorobowymi chwościka poddawano 12-godzinnej inkubacji w wilgotnej komorze. Za pomocą igły preparacyjnej z liści pobierano zarodniki konidialne $C$. beticola i sporządzano $\mathrm{z}$ nich wodną zawiesinę, którą rozprowadzano na powierzchni płytki Petriego $\mathrm{z}$ pożywką PDA (Potato Dextrose Agar, Difco). Wzrastające, pojedyncze kolonie o cechach morfologicznych $C$. beticola przeszczepiano na nową pożywkę PDA. Wszystkie izolaty zostały zidentyfikowane na podstawie makro- i mikroskopowych cech morfologicznych gatunku (Ellis 2001). Izolaty były przechowywane do dalszych badań na pożywce PDA w warunkach chłodniczych.

\section{Badania odporności na strobiluryny}

Badaniami objęto około 150 izolatów C. beticola zbieranych w latach 2012-2013 na terenie Wielkopolski. Ocenę stopnia odporności na strobiluryny wykonano na pożywce PDA zawierającej dodatek piraklostrobiny (Sigma). Substancja czynna została rozpuszczona w metanolu w stężeniu $5 \mathrm{mg} / \mathrm{ml}$. Do pożywki dodawano taką ilość roztworu, aby uzyskać końcowe stężenie substancji czynnej: 1, 3 i 10 ppm. Na pożywki zaszczepiano niewielki fragment grzybni pobrany $\mathrm{z}$ dwutygodniowej kultury rosnącej na pożywce PDA bez dodatku fungicydu. Kontrolę stanowiły kolonie grzyba rosnące na pożywce PDA (bez substancji czynnych). Po 7 dniach inkubacji w temperaturze pokojowej mierzono wzrost liniowy wszystkich izolatów i wyznaczano stopień hamowania wzrostu grzybni przez badane fungicydy w stosunku do wzrostu kolonii kontrolnej rosnącej na czystej pożywce PDA. W badaniach przyjęto następujące oznaczenia: 0 - izolaty całkowicie wrażliwe, brak wzrostu, 1 - wrażliwe (1-20\% wzrostu w stosunku do średnicy kolonii kontrolnej), 2 - średnio wrażliwe (21-50\%), 3 - odporne (51-80\%), 4 - wysoce odporne (> 81\%). Do dalszych badań wykorzystano izolaty $C$. beticola charakteryzujące się podwyższoną odpornością na piraklostrobinę oraz całkowicie wrażliwe.

\section{Badania genetyczne}

Badaniami objęto 22 izolaty C. beticola, charakteryzujące się podwyższoną odpornością na strobiluryny oraz izolat całkowicie wrażliwy. Izolację DNA przeprowadzono ze świeżej grzybni rosnącej na stałej pożywce PDA. Grzybnię oddzieloną od podłoża przenoszono do moździerza i rozcierano na jednolitą masę. Izolację przeprowadzono przy użyciu zestawu „DNeasy Plant Mini Kit” (Qiagen) według protokołu producenta. Do analiz przygotowano roztwór DNA o stężeniu $30 \mathrm{ng} / \mu \mathrm{l}$. W reakcji PCR (polymeraze chain reaction) zastosowano startery cytbSF i cyrbSR (Malandrakis i wsp. 2011) pozwalające na amplifikację fragmentu DNA kodującego białko cytochromu b o wielkości około 750 pz. Reakcję PCR przeprowadzono $\mathrm{w}$ mieszaninie reakcyjnej o końcowej objętości $20 \mu 1$, która zawierała: po $0,3 \mu 110 \mathrm{mM}$ starterów, $2 \mu \mathrm{l}$ Dream Tag PCR Bufor (Fermenthas), 0,3 $\mu \mathrm{l}$ dNTP mix (Fermentas), 0,1 $\mu$ l Dream Taq Polimerase (Fermentas), 60 ng DNA. Zastosowano następujący profil termiczny reakcji PCR: wstępna denaturacja przez $5 \mathrm{~min} \mathrm{w} 94^{\circ} \mathrm{C}$; 39 cykli obejmujących: denaturację $40 \mathrm{~s} \mathrm{w} 95^{\circ} \mathrm{C}$, hybrydy- 
zację starterów $30 \mathrm{~s} \mathrm{w} 52^{\circ} \mathrm{C}$, elongację $40 \mathrm{~s} \mathrm{w} 72^{\circ} \mathrm{C}$; końcową elongację $-5 \mathrm{~min} \mathrm{w} 72^{\circ} \mathrm{C}$. Analizę wyników sekwencjonowania w celu oznaczenia mutacji G143A i F129L przeprowadzono przy użyciu programu MEGA 5.1.

\section{Badania aktywności alternatywnej oksydazy}

Do analizy wytypowano 10 izolatów $C$. beticola charakteryzujących się podwyższoną odpornością na strobiluryny. W badaniach wykonano oznaczenia aktywności alternatywnej oksydazy, enzymu zastępującego funkcje dezaktywowanego przez strobiluryny cytochromu b. Analizę wykonano przez pomiar hamowania wzrostu kolonii (wyrażony w procentach w stosunku do kontroli) rosnących na podłożu PDA $\mathrm{z}$ dodatkiem azoksystrobiny, piraklostrobiny i tiofanatu metylu (w stężeniu $1 \mathrm{ppm}$ ) oraz wyżej wymienionych substancji czynnych (w stężeniu 1 ppm) i SHAM (kwas salicylohydroksyamonowy - SigmaAldrich, w stężeniu 100 ppm). Substancje czynne fungicydów zostały rozpuszczone w metanolu w stężeniu $5 \mathrm{mg} / \mathrm{ml}$, a SHAM w stężeniu $100 \mathrm{mg} / \mathrm{ml}$. Na pożywki zaszczepiano niewielki fragment pobrany z dwutygodniowej grzybni rosnącej na pożywce PDA bez dodatku fungicydu. Kontrolę stanowiły kolonie grzyba rosnące na pożywce PDA (bez substancji czynnych). Po 10 dniach inkubacji w temperaturze pokojowej mierzono wzrost liniowy wszystkich izolatów i wyznaczano stopień hamowania wzrostu grzybni przez badane substancje czynne i SHAM W stosunku do wzrostu kolonii kontrolnej rosnącej na czystej pożywce PDA (bez substancji czynnych i SHAM).

\section{Wyniki i dyskusja / Results and discussion}

C. beticola reprezentuje grupę patogenów szybko nabywających odporność na stosowane substancje czynne fungicydów. Wśród przyczyn tego zjawiska wymienia się możliwość wielokrotnego powtarzania infekcji roślin w czasie sezonu wegetacyjnego, wytwarzanie dużej liczby zarodników konidialnych, a także dużą zmienność genetyczną patogena (Ma i Michailides 2005; Deising i wsp. 2008). Wśród badanych izolatów $C$. beticola zbieranych w roku 2012 - 14,7\% było odpornych lub wysoce odpornych na piraklostrobinę dodaną do pożywki w stężeniu 1 ppm. Wzrost stężenia piraklostrobiny w pożywce powodował spadek liczby izolatów odpornych i wysoce odpornych do $4,8 \%$ dla stężenia 3 ppm i 2,2\% dla 10 ppm (Pieczul i Perek 2013). Wśród izolatów zbieranych w roku 2013 blisko $28 \%$ było odpornych na piraklostrobinę dodaną do pożywki w stężeniu 1 ppm. Przy stężeniu 3 ppm nastąpił spadek liczby izolatów odpornych do 3,3\%, a przy stężeniu 10 ppm do 0 .

Wszystkie badane izolaty (22), których DNA poddane zostało analizie sekwencyjnej posiadały taką samą sekwencję badanego fragmentu genu cytb. Nie stwierdzono obecności mutacji w pozycjach 143 (zamiana glicyny alaniną) oraz 129 (zamiana fenyloalaniny leucyną), które wymieniane są wśród podstawowych czynników warunkujących odporność na strobiluryny notowaną u izolatów C. beticola. W latach 2003-2008 w badaniach prowadzonych na terenie stanu Minesota (USA) nie odnotowano gwałtownego wzrostu odporności izolatów C. beticola na strobiluryny (Secor i wsp. 2010), jednak w 2012 roku ci sami autorzy odnotowali pojawienie się izolatów odpornych na strobiluryny, posiadających mutację G143A. Badania te poparte są wynikami prezentowanymi przez inny zespół (Kirk i wsp. 2012; Bolton i wsp. 2013). Brak rozpoznania szczepów $C$. beticola z mutacjami G143A i F129L wśród badanych izolatów nie wyklucza możliwości pojawiania się ich w najbliższych latach lub obecności na plantacjach, w lokalizacjach nie objętych badaniami. Obserwacje prowadzone $\mathrm{w}$ innych krajach

Tabela 1. Hamowanie wzrostu izolatów C. beticola przez strobiluryny i SHAM [\%]

Table 1. Growth inhibition of C. beticola isolates by strobilurins and SHAM [\%]

\begin{tabular}{c|c|c|c|c|c|c|c}
\hline $\begin{array}{c}\text { Numer izolatu } \\
\text { Isolate number }\end{array}$ & \multicolumn{7}{|c}{$\begin{array}{c}\text { Hamowanie wzrostu w stosunku do kolonii kontrolnej [\%] } \\
\text { Growth inhibition compared to the control colonies [\%] }\end{array}$} \\
\hline & SHAM & KM + SHAM & KM & PYR + SHAM & PYR & AZO + SHAM & AZO \\
\hline 1 & 9,62 & 69,23 & 30,77 & 78,85 & 43,27 & 53,85 & 28,85 \\
\hline 2 & $-5,13$ & 30,77 & $-20,51$ & 52,31 & $-7,69$ & 34,62 & $-25,64$ \\
\hline 3 & 4,53 & 55,47 & 23,40 & 70,57 & 38,68 & 75,47 & 26,42 \\
\hline 4 & $-31,62$ & 65,22 & 22,92 & 66,40 & 54,55 & 53,56 & 11,07 \\
\hline 5 & $-0,76$ & 60,08 & 11,41 & 64,64 & 24,90 & 51,52 & 9,70 \\
\hline 6 & 35,71 & 80,36 & 25,71 & 75,71 & 36,61 & 68,75 & 25,89 \\
\hline 7 & $-7,39$ & 24,63 & $-9,85$ & 45,81 & 5,17 & 29,80 & $-10,84$ \\
\hline 8 & 23,26 & 69,77 & 18,60 & 69,77 & 27,33 & 59,30 & 9,88 \\
\hline 9 & 0,00 & 18,91 & $-7,14$ & 43,28 & 1,26 & 24,37 & $-21,85$ \\
\hline 10 & $-4,69$ & 63,38 & $-7,04$ & 58,69 & 8,45 & 60,09 & $-11,50$ \\
\hline 11 & 1,10 & 54,21 & 28,57 & 65,20 & 34,98 & 50,55 & 20,33 \\
\hline $\begin{array}{c}\text { Średnia } \\
\text { Mean }\end{array}$ & 2,23 & 53,82 & 10,62 & 62,83 & 24,31 & 51,08 & \multirow{2}{*}{5,66} \\
\hline
\end{tabular}

SHAM - kwas salicylohydroksyamonowy, KM - krezoksym metylu, PYR - piraklostrobina, AZO - azoksystrobina

SHAM - salicylhydroxamic acid, KM - kresoxim-methyl, PYR - pyraclostrobin, AZO - azoxystrobin 
wskazują, że pojawianie się szczepów C. beticola z wyżej wymienionymi mutacjami łączy się $\mathrm{z}$ coraz powszechniejszym stosowaniem strobiluryn.

Wśród innych przyczyn odporności izolatów $C$. beticola na strobiluryny wymienia się wzrost aktywności alternatywnej oksydazy (Fernandez-Ortuno i wsp. 2008). Przeprowadzone badania potwierdzają te obserwacje. Średni procent hamowania wzrostu badanych izolatów znacznie wzrasta przy jednoczesnym dodaniu do pożywki SHAM i fungicydu niż jedynie fungicydu. Średni stopień hamowania wzrostu kolonii $C$. beticola wynosił dla: krezoksymu metylu - 10,6\%; krezoksymu metylu i SHAM - 54\%; piraklostobiny - 24\%; piraklostrobiny i SHAM - 63\%; azoksystrobiny - 5,5\%; azoksystrobiny i SHAM - 51\%. Zwiększona odporność badanych izolatów C. beticola na strobiluryny spowodowana jest wzmożoną aktywnością alternatywnej oksydazy, zastępującej funkcję cytochromu b w szlaku oddechowym. SHAM blokuje działanie alternatywnej oksydazy, przez co wzrasta skuteczność działania fungicydów. Działanie alternatywnej oksydazy jest jednak ograniczone, szlak ten dostarcza znacznie mniej energii, niż uzyskiwane jest to $\mathrm{w}$ normalnych procesach oddechowych zachodzących na kompleksie III. Deficyty te przekładają się na mniejszą efektywność procesów, które wymagają dużych nakładów energetycznych, jak np. kiełkowanie zarodników czy początkowe stadia infekcji roślin (Fernandez-Ortuno i wsp. 2008; Wood i Hollomon 2003). Dane te mogą tłumaczyć niewielkie znaczenie izolatów o podwyższonej odporności na strobiluryny w rozwoju i rozprzestrzenianiu chwościka oraz wysoką skuteczność stosowania strobiluryn w jego zwalczaniu. Część wyników wskazuje, że mutanty odporne na strobiluryny są w gorszej kondycji fizjologicznej, objawiającej się spadkiem patogeniczności i zdolności produkcji konidiów (Fernandez-Ortuno i wsp. 2008).

\section{Wnioski / Conclusions}

1. Wśród badanych izolatów C. beticola nie stwierdzono mutacji G143A oraz F129L, które wymieniane są jako podstawowe czynniki warunkujące odporność na strobiluryny.

2. Zwiększona odporność badanych izolatów spowodowana jest wzmożoną aktywnością alternatywnej oksydazy, zastępującej funkcję cytochromu b w szlaku oddechowym.

3. Ze względu na możliwość nabywania przez C. beticola odporności spowodowanej mutacjami G143A oraz F129L skuteczność stosowanych fungicydów powinna być poddawana stałej ocenie.

\section{Literatura / References}

Bolton M.D., Riviera V., Secor G. 2013. Identification of the G143A mutation associated with Qol resistance in Cercospora beticola field isolates from Michigan, United States. Pest Management Science 69: 35-39.

Briere S.C., Franc G.D., Kerr E.D. 2001. Fungicide sensitivity characteristics of Cercospora beticola isolates recovered from the high plains of Colorado, Montana, Nebraska, and Wyoming. Benzimidazole and triphenyltin hydroxide. Journal of Sugar Beet Research 38 (2): $111-120$.

Campbell L.G., Smith G.A., Lamey H.A., Cattanach A.W. 1998. Cercospora beticola tolerant totriphenyltin hydroxude and resistant to tiophanate methyl in North Dacota and Minnesota. Journal of Sugar Beet Research 35 (1-2): 29-41.

Deising H.B., Reiman S., Pascholati S.F. 2008. Mechanism and significance of fungicide resistance. Brazilian Journal of Microbiology 39: $286-295$

Ellis M.B. 2001. More Dematiaceus Hyphomycetes. CABI Publishing, 248 pp.

Fernandez-Ortuno D., Tores J.A., de Vicente A., Perez-Garcia A. 2008. Mechanism of resistance to Qol fungicides in phytopathogenic fungi. International Microbiology 11: 1-9.

Fisher N., Meunier B. 2008. Molecular basis of resistance to cytochrome bc1 inhibitor. FEMS Yeast Research 8: 183-192.

Gisi U., Sierotzki H., Cook A., McCaffery A. 2002. Mechanisms influencing the rvolution of resistance to Qo inhibitor fungicides. Pest Management Science 58: 859-867.

Karaoglanidis G.S., Thanassoulopoulos C.C. 2003. Cross-resistance patterns among sterol biosynthesis inhibiting fungicides (SBIs). European Journal of Plant Pathology109 (9): 929-934.

Kirk W.W., Hanson L.E., Franc G.D., Stump W.L., Gachango E., Clark G., Stewart J. 2012. First report of strobilurin resistance in Cercospora beticola in sugar beet (Beta vulgaris) in Michigan and Nebraska, USA. New Disease Reports 26, p. 3.

Ma Z., Michailides T.J. 2005. Advances in understanding molecular mechanism of fungicide resistance and molecular detection of resistant genotypes in phytopathogenic fungi. Crop Protection 24: 853-863.

Malandrakis A., Markoglou A., Nikou D., Vontas J., Ziogas B. 2011. Molecular diagnostic for detecting the cytochrome b G143S - Qol resistance mutation in Cercospora beticola. Pesticide Biochemistry and Physiology 100: 87-92.

Pieczul K., Perek A. 2013. Odporność na fungicydy izolatów Cercospora beticola pochodzących z terenu Wielkopolski. [Fungicide resistance of Cercospora beticola isolates collected from Wielkopolska region]. Progress in Plant Protection/Postępy w Ochronie Roślin 53 (4): 796-800.

Piszczek J. 2010. Epidemiologia chwościka buraka cukrowego (Cercospora beticola) w Centralnej Polsce. Rozprawy Naukowe Instytutu Ochrony Roślin - Państwowego Instytutu Badawczego 23, 70 ss.

Secor G.A., Rivera V.V., Khan M.F.R., Gudmestad N. 2010. Monitoring fungicide sensitivity of Cercospora beticola of sugar beet for disease management decisions. Plant Disease 94 (11): 1272-1282.

Weiland J.J., Halloin J.M. 2001. Benzimidazole resistance in Cercospora beticola sampled from sugarbeet fields in Michigan, USA. Canadian Journal of Plant Pathology 23: 78-82.

Wood P.M., Hollomon D.W. 2003. A critical evaluation of the role of alternative oxidase in the performance of strobilurin and related fungicides acting at the Qo site of complex III. Pest Management Science 59: 499-511. 